\title{
In vitro Antimicrobial Activity and Phytochemical Screening of Local Plants
}

\author{
Shital Chandrashekhar Lolge, Sunita Pandit Zanke, Dipti Ramrao Patil and Sureshchandra Popat Zambare \\ Department of Zoology, Dr. BabasahebAmbedkarMarathwada University, Aurangabad, 431004 (M.S.) India
}

\begin{abstract}
Antimicrobial activity of extracts of local plants was evaluated, with two strain i.e E. coli and S. aurri (gram positive and gram negative) microorganisms. The in vitro anti bacterial activity was performed by agar disc diffusion method. The most active antibacterial plants were $S$. trifiliatus and A. mexicana. The significant antibacterial activity of active extracts was compared with the standered, antimicrobics, streptomycin $(10 \mu \mathrm{g} / \mathrm{disc})$. The results obtained in the present study suggest that $S$. trifoliatus and A. mexicana can be used in treating diseases caused by the test organism.
\end{abstract}

Key word: Antimicrobial, antibacterial, plant extract, S. trifoliatus, A. mexicana.

\section{Introduction}

India is a richest country in the world in regard to medicinal plants and their genetic resources. About $80 \%$ of people use traditional medicine [1] containing a wide variety of compounds that can be used to treat chronic as well as infectious diseases.

Many plants have been used for antioxidant and antimicrobial properties which are due to secondary plants metabolites (Phytochemicals) [2].

Phytochemicals are non-nutritiveplant chemicalthathave protective or diseases preventive properties. Plant produces these chemicals to protect itself, but recent research demonstrates that many Phytochemicals that protect human against diseases. These are many Phytochemicals in leaves and seeds and each works differently [3]. Many plant extracts have been shown to inhibit the growth of microorganisms. These extracts are usually considered to play a role in defence reactions of plants against infections by pathogenic (bacteria) microorganisms [4].

Everyone is always surrounded by number of microbes. The emergence and spread of microbes

Corresponding author: Shital Chandrashekhar Lolge, M.sc, research field: applied biology. resistance represent a global problem. Infectious disease caused by the microbes and resistance developed by them are an important health hazard all over the developing and developed countries.

The aim of this study is to the activity of extracts from plants against gram positive and gram negative bacterial strains in vitro.

\section{Material and Methods}

\subsection{Collection and Identification of Plant Material}

Fresh 8 plants (P. aculata, A. mexicana, A. squmosa, $S$. anacardium, $S . \quad$ cumini, $S$. trifoliatus, $S$. xanthocarpum) leaves and seeds were collected from areas of and around university campus, Aurangabad, Maharashtra, India. The taxonomic identification of these plants was confirmed from department of Botany, Dr. Babasaheb Ambedkar Marathwada University, Aurangabad and voucher specimen numbers of the plants were preserved. The plant material was washed under running tap water, air dried for 2-3 weeks at room temperature $\left(37^{\circ}-40^{\circ} \mathrm{c}\right)$ and pulverized in an electric grinder and stored in airtight bottles.

\subsection{Preparation of the Extract}

$20 \mathrm{gm}$ of plant powder was soaked in $200 \mathrm{ml}$ methanol, ethanol, acetone and chloroform solvents 
and extracts were extracted with Soxhlet apparatus [5].

\subsection{Phytochemical Screening}

Phytochemical screening were performed assay the qualitative chemical composition of crude extract of eight plants to identify the major secondary metabolites like alkaloids, flavonoids, saponins, phenolic compounds, tannins [6].

\subsection{Antimicrobial Screening}

Test organism: Escherichia coli (gram - ve) and Staphylococcus aureus (gram + ve) bacteria were used for antibacterial activity tests. Standard strains obtained from NCL (National Chemical Laboratory), Pune, India. The microorganisms were maintained at 4 ${ }^{\circ} \mathrm{C}$ on nutrient agar slants.

\subsection{Preparation of the Test Solutions and Antimicrobial Assay Using Disk Diffusion Methods}

Antimicrobial activity was carried out according to the method of [7] stock cultures were maintained at $4{ }^{\circ} \mathrm{C}$ on slope of nutrient agar and $200 \mu \mathrm{l}$ of standardized cell suspensions were spread on a nutrient agar. Extracts of alleight plants (leaves and seeds) were dissolved in methanol, ethanol, chloroform, acetone and aliquote $10 \mu \mathrm{l}$ of extracts. The sample were observed by disc paper and air dried. After air dried disc with extract were inoculated on agar plate against selected microorganisms (E. coli and S. aureus). After $24 \mathrm{hrs}$ of incubation the results were recorded in different time interval. The effects of plant extract were compared with Streptomycin as standard drugs at $1 \mathrm{mg} / \mathrm{ml}$ concentration. The result was obtained by measuring the zone diameter.

\section{Result and Discussion}

The antibacterial activity of eight plant species extract was assayed in vitro by agar disc diffusion method against Gram - ve and Gram + ve bacterial species. The solvent extracts of only three showed antibacterialactivity (C. auriculata, A. mexicana, $S$. trifoliatus) the other extracts did not show any antibacterial activity. The significant antibacterial activity of the active plant extracts was comparable to the standard antimicrobics Streptomycin $(100 \mu \mathrm{g} / \mathrm{disc})$.

The secondary metabolites like tannins, flavonoids, steroids, saponines and alkaloids were present in trace amount in some of the plants (Table 1). Tables 2 and 3 summarize the microbial growth of different solvent extracts of screened plants against E. coli (Gram - ve bacteria) and $S$. aureus (Gram + ve bacteria) respectively. It is not surprising that there are differences in the antibacterial effects of plant species, due to the phytochemical properties and differences among species. It is quite possible that some of the plants that were ineffective in this study do not possess antibiotic properties, or the plant extracts may have contained antibacterial constituents, just not in sufficient concentrations so as to be effective. The drying process may have caused conformational changes

Table 1 Preliminary phytochemical analysis of screened plant species (10).

\begin{tabular}{|c|c|c|c|c|c|c|c|c|}
\hline Sr.no & Plant species & Tannins & Saponins & Phenols & Flavonoids & Terpenoid & Steriods & Alkaloids \\
\hline 1 & P.aculata $(L)$ & - & + & + & + & - & - & + \\
\hline 2 & C.auriculata $(L)$ & + & + & + & + & - & + & + \\
\hline 3 & A.maxicana $(S)$ & + & + & + & + & - & + & + \\
\hline 4 & A.squamosa $(S)$ & + & + & - & - & + & + & + \\
\hline 5 & S.trifoliatus $(S)$ & - & + & - & - & - & - & - \\
\hline 7 & P.aculata $(S)$ & - & + & + & + & - & - & + \\
\hline 8 & S.cumini $(S)$ & + & + & + & + & - & + & + \\
\hline 9 & S.xanthocarpum $(S)$ & - & + & + & + & - & + & + \\
\hline
\end{tabular}

L=Leaf; $\mathrm{S}=$ Seed. 
Table 2 Antimicrobial activity of different solvent extracts of screened plants against E. coli (Gram - ve bacteria).

\begin{tabular}{lllllll}
\hline Sr.no & Plant species & Control (Steptomycin) & Acetone & Methanol & Ethanol & Chloroform \\
\hline 1 & P.aculata $(L)$ & +++ & - & - & - & - \\
2 & C.auriculata $(L)$ & +++ & ++ & ++ & + & - \\
3 & A.maxicana $(S)$ & +++ & + & ++ & ++ & + \\
4 & A.squamosa $(S)$ & +++ & - & - & - & - \\
5 & S.trifoliatus $(S)$ & +++ & ++ & ++ & ++ & ++ \\
6 & S.anacardium $(S)$ & +++ & - & - & - & - \\
7 & P.aculata $(S)$ & +++ & + & - & - & - \\
8 & S.cumini $(S)$ & ++ & - & - & - & - \\
9 & S.xanthocarpum $(S)$ & +++ & - & - & - & - \\
\hline
\end{tabular}

Table 3 Antimicrobial activity of different solvent extracts of screened plants against S. aureus (Gram + ve bacteria).

\begin{tabular}{lllllll}
\hline Sr.no & Plant species & Control (Steptomycin) & Acetone & Methanol & Ethanol & Chloroform \\
\hline 1 & P.aculata $(L)$ & +++ & + & ++ & + & - \\
2 & C.auriculata $(L)$ & +++ & - & + & + & ++ \\
3 & A.maxicana $(S)$ & +++ & - & + & + & + \\
4 & A.squamosa $(S)$ & +++ & + & + & - & - \\
5 & S.trifoliatus $(S)$ & ++ & + & - & ++ & - \\
6 & S.anacardium $(S)$ & +++ & + & - & - & - \\
7 & P.aculata $(S)$ & ++ & - & ++ & - & - \\
8 & S.cumini $(S)$ & +++ & - & - & - & - \\
9 & S.xanthocarpum $(S)$ & +++ & - & & - & - \\
\hline
\end{tabular}

to occur in some of the chemical constituents found in these plants.

Similar results were reported by Venkatesan et al (2005), Prescott et al (1999) and Stainer et al (1986) [8-11] who reported diseases such as Pneumonia, urinary and respiratory tract infections caused by Klebsiella species.

\section{Conclusion}

In conclusion, $S$. trifoliatus extracts possess a broad spectrum of activity against a panel of bacteria responsible for the most common bacterial disease. These promissory extracts open the possibility of finding new clinically effective antibacterial compounds.

\section{Acknowledgements}

We are thankful to prof.and Head of Dept. of Zoology Dr. Babasaheb Ambedkar Marathadwada University, Aurangabad (M.S.) for providing laboratory facility.

\section{References}

[1] Fqwole, O. A, Amoo, S. O., Nahlala, A. R., Light, M. E., Finnie, J. F., and Van Staden, J. 2010. “Anti-inflammatory, Anticholinesterase, Antioxidant and Phytochemical Properties of Medicinal Plants Used for Pain Related Ailments in South Africa." J. Ethnopharmacol 127 (2): 235-41.

[2] Balandrin, M. F., Kjocke, A. J., Wurtele, E., et al. 1985. "Natural Plant Chemicals, Sources of Industrial and Mechanical Material." Science 228: 1154-60.

[3] Argal, A., and Pathak, A. K. 2006. "CNS Activity of Calotropisgigantearoots.” J. Ethnopharmacol. 106: 142-5.

[4] Fawcett, C. H., and Spencer, D. M. 1976. "Plant Chemotherapy with Natural Products." Аnnu. Rev. Phytopathol. 8: 403-18.

[5] Harbone, J. B. 1973. "Phytochemical Methods." London: Chapman and Hill.

[6] Sofowora, A. 1993. "Medicinal Plants and Traditional Medicine in Africa." Spectrum Book Ibadan, 150.

[7] Bauer, A. W., Kirby, W. M, Sherris, J. C., and Turck, M. 1996. "Antibiotic Susceptibility Testing by a Standardized Single Disk Method.” Am. J. Clin. Pathol. 45 (4): 493-6.

[8] Prescott, L. M., Harley, J. P., and Klein, D. A. 1999. "Microbiology 4th ed." Boston: The McGraw Hill Companies Inc., 685. 
[9] StainerRy, Ingraham, J. L., Wheelis, M. L., et al. 1986. “General Microbiology 5th ed." London: The Macmillan Press Ltd.

[10] Trease, G. E., and Evans, W. C. 1989. "Pharmacognosy 13th ed.” London: Bailliere Tindal, 176-80.

[11] Venkatesan, M., Vishwanathan, M. B., Ramesh, N., et al. 2005. "Antibacterial Potential from Indian Suregada angustifolia.” J. Ethnopharmacol. 99: 349-52. 